\title{
Fluvial dynamics and selected methods of ecohydrological monitoring of restored Sviňovický brook channel
}

\author{
ZDENĚK KLIMENT ${ }^{1}$, MILADA MATOUŠKOVÁ ${ }^{1}$, MIROSLAV ŠOBR $^{1}$, \\ MARKÉTA POTU゚ČKOVÁ ${ }^{2}$ JANA HUJSLOVÁ ${ }^{1}$ \\ ${ }^{1}$ Charles University in Prague, Faculty of Science, \\ Department of Physical Geography and Geoecology \\ ${ }^{2}$ Charles University in Prague, Faculty of Science, \\ Department of Applied Geoinformatics and Cartography
}

\begin{abstract}
This paper concentrates on monitoring and the evaluation of the restored Sviňovický brook channel. Main attention is paid to fluvial dynamics of the new channel. Repeated measurement of the cross-section and longitudinal profiles of the channel in connection with the rainfall and run-off events which have occurred can be considered as the basic method. In addition experimental photogrammetric methods have been applied using aerial images of the area taken from low-flying model planes. So far the largest changes to the revitalized channel occurred during the floods in July 2006. The flood caused changes in depth reaching more than $30 \mathrm{~cm}$ and in width reaching up to 1 metre, thus creating new conditions for further development of the channel. Changes in the course of the monitored channel in the historical period between 1843 and 2005 have been studied separately based on an analysis of the maps and aerial images. In connection with this research, selected methods of ecohydrological monitoring have been applied: surface water quality monitoring based on the hydrochemical parameters and also assessment of hydromorphological structures of the river habitat quality.
\end{abstract}

Key words: Fluvial dynamics - channel development - restoration - ecohydromorphological monitoring Sviňovický Brook

\section{Introduction}

The main aims of the restoration projects include improvement of the negative consequences of inappropriate land changes previously performed, inappropriate landuse and large-scale drainage; an increase in the water retention ability of the landscape by slowing down the surface and subsurface runoff; a revitalization of the water ecosystems; and an increase in the self-cleaning ability of the water.

Returning a river to a former or more semi-natural state is a challenging prospect. In its purest sense, restoration means the full structural and functional return of a river to a pre-disturbance state, an opportunity which rarely occurs for the whole of a river. In most cases rehabilitation indicates a process which can be defined as the partial functional and/or structural return to a former or pre-degradation condition or putting back to good working order (Waal et al. 2000).

Restoration must be seen as an effort to create, or better stimulate, the natural development of the given river, which is related to the hydromorphology and 
morphometry of the channel, hydrology and rainfall-runoff process, quality characteristics and sediment load regime, natural composition of water flora and fauna, and riparian belt. This is a long-term process and it cannot be expected that the hydromorphological condition of the river channel will change significantly in one or two years. Kern (1994) states that for a straightened and artificially reverted river to achieve dynamic balance during spontaneous redevelopment it takes approximately 50 years after it has been "freed". However, this time can differ considerably for different rivers. The variability of the rainfall-runoff process is the decisive factor, with the existence of riverbed-forming flow being particularly essential.

The beginnings of the restoration projects in practice were dominated by the tendency towards the artificial anthropogenic formation of near natural fluvialmorphological structures making use of the stabilizing effect of natural materials. However, the requirements for the eco-hydrological functions of rivers have gradually increased. The large amounts of money spent on restoration projects with artificially created near natural structures usually attain only average results. Therefore, the tendency to allow the spontaneous natural hydromorphological development of river channels has gradually prevailed (Matoušková 2003). The importance of studies dealing with the hydromorphological development of restored river channels has grown as they can be used for evaluating the effect of the restoration changes carried out. In the Czech Republic, this topic has been studied by Šindlar (1998), Zuna (2001) and Vrána (2004). Under the patronage of the Ministry for Environment, a study "Restoration of morphological variation of the brook channel" has been conducted which dealt with the changes in morphology and load regime of channels after their restoration (Zuna 2001). A subsequent study was carried out under the leadership of Vrána, Gergel and Zuna which included 20 different restored streams. The field research included assessment of stability, durability, functioning of individual inserted elements and their effect on the migration permeability of the river, the method of maintenance and development of the riparian belt, bottom levelling and taking samples of water. Unified methodology for quantifying the success rate of the restoration carried out has not been created based on the research (Kujanová 2008). According to Just (2005), it is more suitable to evaluate restoration effects individually for restorations in various geographical conditions. However, it is possible to define criteria based on which restoration effects can be evaluated. The main problem for revitalization effect evaluation is the length of time given to the restored river which is necessary for the renewal of the original fluvial-morphological and morphometric characteristics of the channel. It is also difficult to define the resulting river type as it is a result of many factors interacting together (Matoušková 2003). Brooks (1988) evaluated the development of 300 smaller rivers which had been stripped of artificial channel fortification and left to develop spontaneously. The original sinuosity of the channel course and its morphometric characteristics were renewed in only 13 cases. More complex evaluation criteria, including biological component are presented in Hubačíková, V., Oppeltová, P. (2008). The interaction between fluvial-morphological river habitat structures and macroinvertebrates was studied by Grešková et al. (2007).

The aim of the research is to monitor the stability and development of the restored channel of the Sviňovický Brook in the Blanice source area on the boundary between 


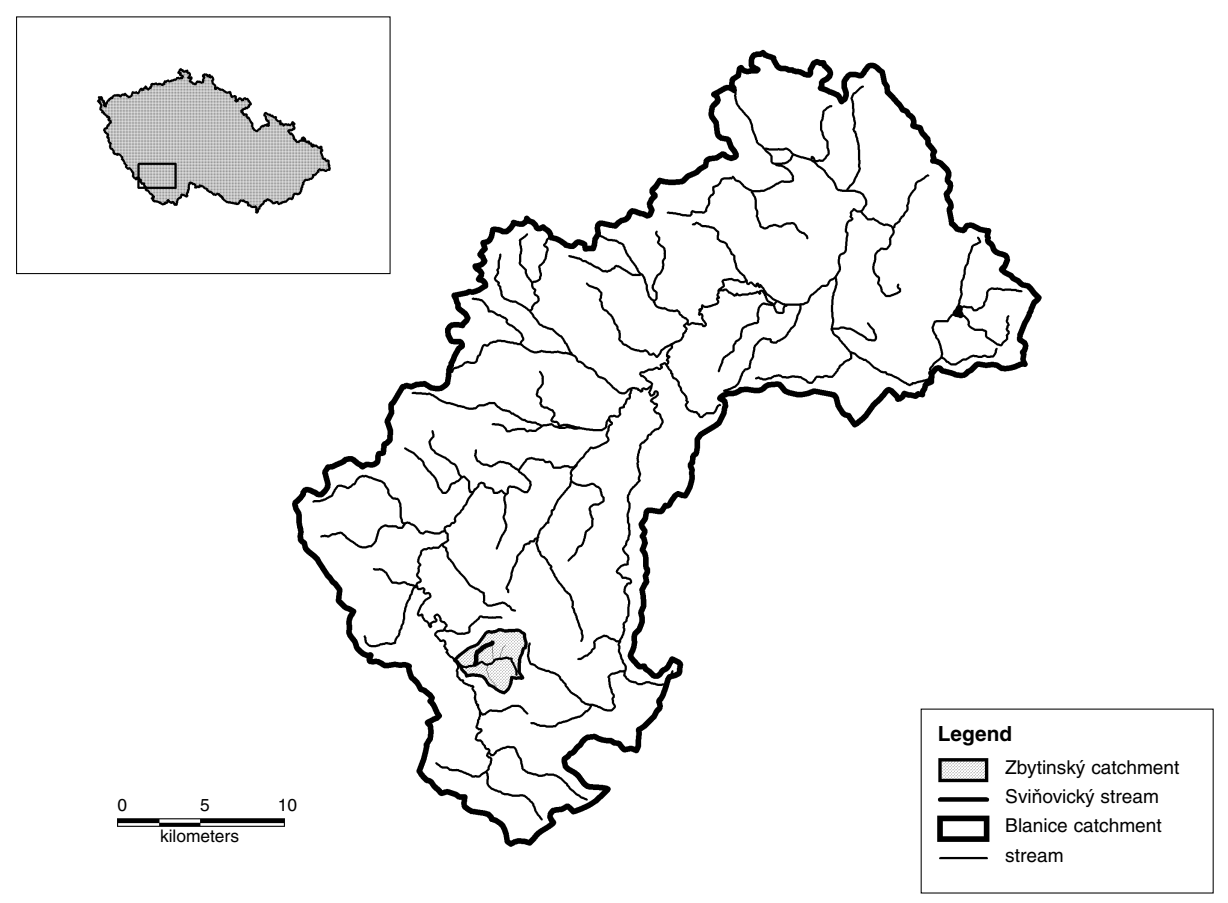

Figure 1: Location of the study area

Šumava and the Šumava foothills with respect to the occurrence of extreme rainfallrunoff events and to evaluate the successfulness of the restoration measures carried out in 2005 from the point of the renewal of the ecohydrological function of this significant landscape feature (Fig. 1). Together with the elementary fluvial-geomorphological research of the revitalized channel, ecohydrological monitoring is carried out, which checks the water quality and carries out an ecohydromorphological mapping of the habitat quality. This will serve as one of the sources for the evaluation of the restoration effect.

The fluvial-geomorphological and hydrological research started immediately after the restoration and still continues. Hydrochemical monitoring has been carried out since January 2006. The ecohydromorphological mapping was carried out in spring 2008 and it is expected that this will be repeated regularly. The contribution concentrates on the presentation of the methods applied and outputs of the analyses carried out so far.

\section{Characteristics of the study area}

The source of the Sviňovický Brook is not far from the settlement Sviňovice, northwest of the village Zbytiny. It is the right tributary of the Zbytinský Brook, which 
empties from the right hand side to the Blanice River west of Zbytiny. The length of the brook is $1.8 \mathrm{~km}$ and the area of the elongated water basin is $1.6 \mathrm{~km}^{2}$. The river basin relief sinks from the watershed which runs through the Schánělův hill, the highest Sviňovický hill (934.7 m a.s.1.), and Suchý hill (818 m a.s.l.) to the river valley and to its mouth into the Zbytinský Brook (at approximately 775 metres above sea level). The geological substrate consists of heavily metamorphosed and migmatized Moldanubicum Pre-cambric to Palaeozoic rocks covered by Pleistocene and Holocene deluvial and fluvial sediments and peat. The prevailing soil type in the catchment of the Sviňovický Brook is modal crypto-podsol, podsol and dystric cambisol, which are characteristic for cold climatic regions. The Sviňovický Brook is surrounded by a stripe of soil types with gleyzation characteristics (stagno-gleyic cambisols, pseudogley soils, and gley soils).

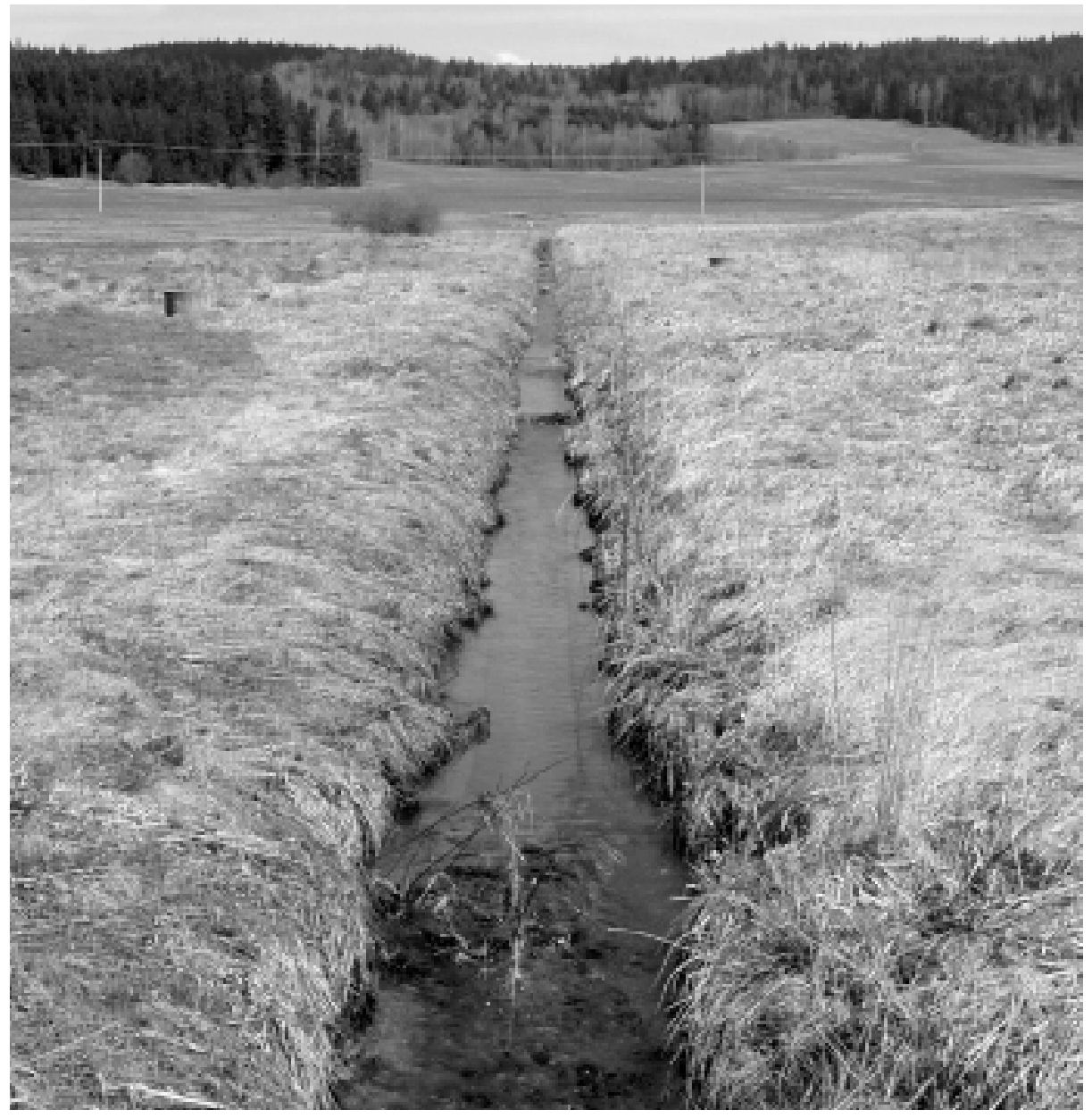

Figure 2: Sviňovický Brook before the restoration, the channel bed and the banks were reverted with concrete components - situation in autumn 2004. Photo: Matoušková 


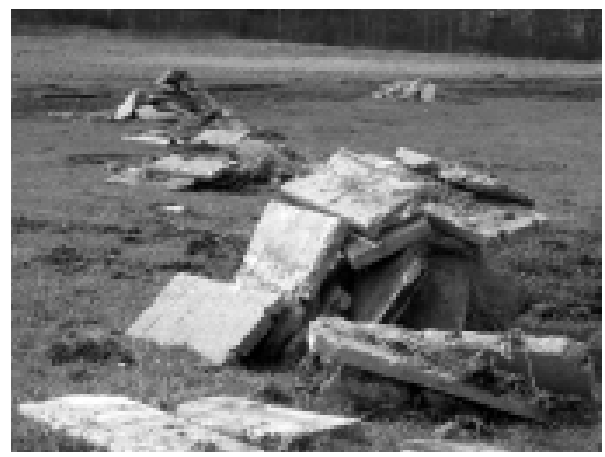

a)

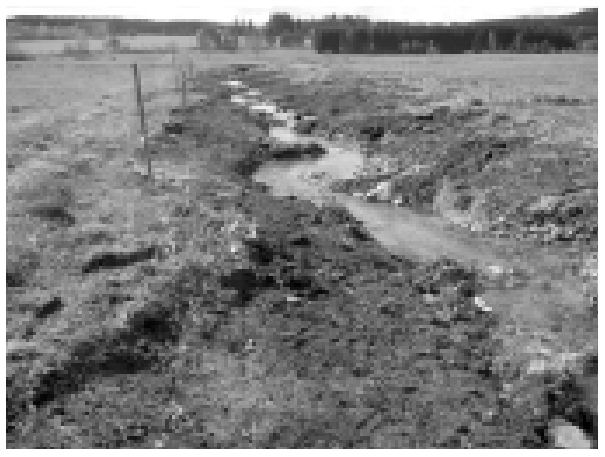

b)

Figure 3: Restored channel of the Sviňovický Brook: a) removed concrete revetment, b) restored channel, closing of the subsurface drainage outlets - situation spring 2005. Photo: Matoušková

The hydrological conditions in the Sviňovický Brook catchment area were significantly changed by human activity in the 1970s and 1980s. Baulks disappeared from the surrounding land which prevented soil being quickly washed off the fields; the land around the brook was drained. The channel was straightened and concreted and the course of the channel changed significantly in the lower reach. At present, the previously arable land is covered with grass and used as meadows and pastures. At the same time, the brook is being restored. The river basin of the Sviňovický Brook is important in terms of protecting the environment because the natural sight "Pod Sviňovicemi" is located here and the most southern part of the area is in the Šmava National Park (the border is parallel with the main road II/165 Zbytiny - Volary).

The restoration of the Sviňovický Brook, together with the adjacent part of the Zbytinský Brook, started in spring 2005. Both parts of the restoration were carried out only in selected reaches so it was not a comprehensive restoration from the source to the mouth. The aims of the restoration were particularly to renew the basic parameters of the brook biotope (increase the depth of the permanent water surface, reduce the speed of the water in the channel, create pools for sediment accumulation), to increase the selfcleaning ability of the water and to reduce the speed of the water discharge from the landscape. After the restoration, the channel should have more bends and its length should increase from $1.1 \mathrm{~km}$ to $1.145 \mathrm{~km}$. The first stage of the restoration was to remove the concrete fortification, starting from the mouth of the Sviňovický Brook to the culvert by the forest at the level crossing TK 60/125 (Fig. 2 and 3). In the upper and lower reaches $(0.000-0.318$ and $0.650-1.145 \mathrm{~km})$, the original channel course was preserved. As part of this, at the $0.100-0.180 \mathrm{~km}$ reach the slopes on both banks were to be reduced to a $1: 5$ incline. At $0.318-0.650 \mathrm{~km}$, a new channel was designed in the shape of a trapezoid, with a $30 \mathrm{~cm}$ base and an alternating one-side incline of $1: 2$ and $1: 5$ (Kohoutek, Tuček 2002).

The concrete components were to be replaced by fortifications in the slope bases using boulders from the surrounding area reaching a size of $20-50 \mathrm{~cm}$. The drainage system in the upper reach remained practically unchanged. In the lower section of the 
channel on the right-hand side, the area drainage was partially removed and the drains were taken out to the surface just before the channel's mouth. This required the channel to be deepened compared to the original situation. The twenty newly created stone rapids in the channel which do not exceed 0.3 metres were to help to increase the stability of the stream bed and the slopes and to improve life in the brook. The riparian belt was planted alongside the brook to stabilize the channel. The types of growth selected included domestic woody species such as common alder, grey alder, ash, purple willow, silver birch and large grey willow. As part of the restoration, two marsh areas are planned to be created below the village of Zbytiny in connection with the sewage plant being built. After significant rainfall-runoff events in July 2006, which affected the natural development of the restored channel, some parts of the channel in the reach above the road bridge were stabilized at the end of 2007 using quarried stone.

\section{Methods applied and data sources}

During the research, both field and photogrammetric (remote sensing) methods were applied. As the basic method we can consider the repeated measurement of twelve cross-section profiles using the Leica total station 705 TCR in 6-month intervals spring - autumn (profiles 1-10 from spring 2005, profiles N1 and N7 from spring 2006) and of the longitudinal profile (from autumn 2005), as well as the

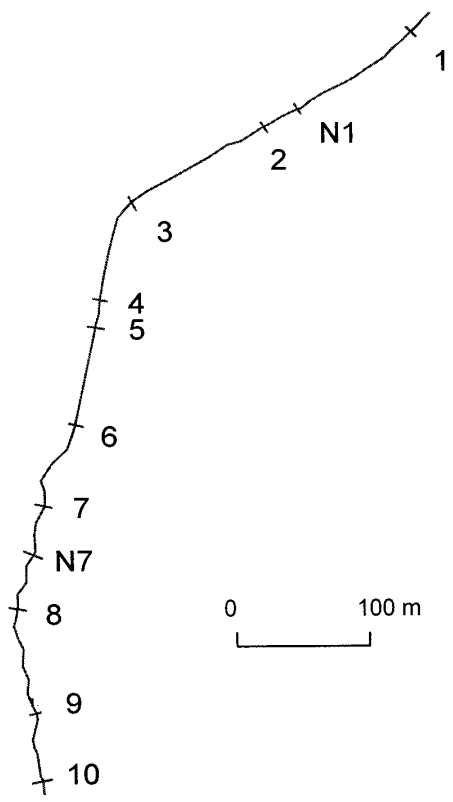

Figure 4: Location of the cross-section profiles of the geodesic measurements of the restored channel of the Sviňovický Brook 
photographic documentation of the channel condition (Fig. 4). The cross-section profiles were marked and stabilized in the field using boundary marks. During the first measurement, the coordinates of the boundary marks were determined in the S-JSTK coordinate system. This was done using a traverse from the trigonometric point "Kamenský les" (orientation towards the densification point Zbytiny - church). Each profile was always measured from a position on the left bank. The direct boundary of the cross profile was always checked carefully according to the value of the horizontal angle.

Images of the studied area were taken using a low-flying model plane in spring 2006 and 2008. A model of a helicopter was used in spring 2007. Both models were provided by the private company Aerodata. Image processing for the purpose of fluvialmorphologic interpretation is currently being carried out. In the first stage of the investigation, the images were geo-referenced into the national coordinate system S JSTK by means of projective transformation. The software package Microstation V8 and its extension Descartes are used for this purpose. The projective transformation solves the relation between the plane of the image and the reference plane; height information is not applied. The presence of height differences in the real terrain causes radial displacements of the points in the transformed images with respect to their correct position. This error increases with the distance from the image centre and height difference to the reference plane. Depending on the height differences between the stream bank and the bottom of the water course, it can reach up to the order of tens of centimetres in some parts of the brook. Therefore, the second stage of the investigation concentrates on possibilities of complete photogrammetric restitution including a 3D model of the stream bed. Due to a relatively low number of control points, a bundle adjustment of a strip of images seems to be the best method for determining the parameters of exterior orientation, i.e. a position and rotations of the images in the reference coordinate system (Kraus 2007). Sufficient forward overlap and relatively small mutual tilts and shifts among the neighbouring images are important prerequisites for successful application of the bundle adjustment calculation. A 3D model of the area and orthoimages are the results of photogrammetric processing of the original images.

Since 2006, water conditions have been continually monitored and hydrometric measurement has been carried out occasionally for the purpose of constructing the rating curve. The data from the automatic ombrometer, located in the experimental river basin not far from Zbytiny, is used to evaluate the rainfall-runoff ratios. The data is compared with the CHMI rainfall measuring station in Spálenec. At the same time, the quality of the surface water is monitored with respect to hydrochemical and hydrobiological factors. In May 2007, the restored channel was also ecomorphologically mapped using the method EcoRivHab (Matoušková 2003, 2007). This will serve as one of the sources for the evaluation of the successfulness of the restoration carried out. The EcoRivHab method was modified slightly for this purpose. The modification particularly concerned the number of evaluated parameters. The river channel zone, riparian belt and wider surrounding of the brook up to 100 metres from both banks were evaluated during the field mapping. The flow speeds were measured using the floating method on 1 May 2008. 
The important part is to identify the state and course of the monitored channel in different historical periods in 1843, 1888, 1950, 1982, 2005 based on the historical maps, plans and aerial images (COSMC, AWMA).

\section{Results}

Historical changes in the course of the Sviňovický Brook

Various maps from the last 180 years were used to identify changes in the course of the Sviňovický Brook channel (Compulsory Imperial Prints of the Land Register of Bohemia from 1824-1843 in $1: 2.880$ scale, map of the area of the village of Zbytiny from 1888 which is kept together with the imperial prints of maps of the land register in the map archive of the Czech Office for Surveying, Mapping and Cadastre (COSMC) in Prague, land register map valid until 1950, real estate register map from

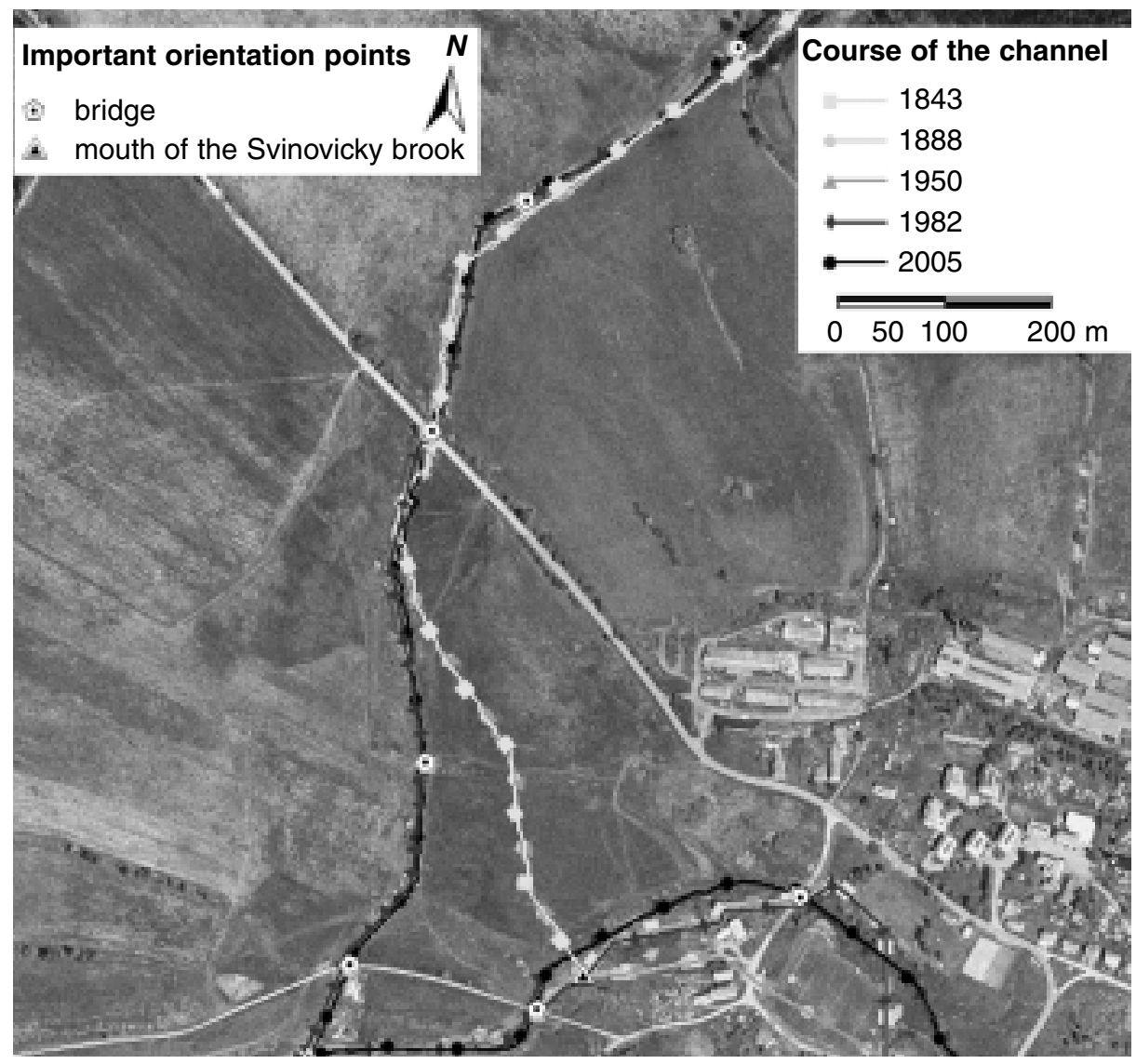

Figure 5: Historical changes in the course of the Sviňovický Brook and the reach of the Zbytinský Brook between 1843 and 2005 
1982, orthoimage of the upper part of Blanice from 2005 - COSMC source). After processing the map sources, the course of the Sviňovický Brook and part of the Zbytinský Brook were put into vectors in the five monitored years - 1843, 1888, 1950, 1982, 2005 (see Fig. 5). In 1843, the character of the channel of the Sviňovický Brook was natural with gentle bends. It ran south-west and, approximately 180 metres north of the road, it turned to the south. Approximately 100 metres from the road the channel's direction changed from the south to south-east. The Sviňovický Brook emptied into the Zbytinský Brook at the start of the village of Zbytiny. The course of the Sviňovický Brook channel in 1888 and in 1951 display only small differences. In the upper part of the brook above the road, the course is practically identical; in the lower part the bends have moved slightly. The Sviňovický Brook was very significantly affected by human activity during the time of agricultural collectivization during socialism in the 1970s and 1980s when amelioration improvement were carried out. It was straightened and a $1.132 \mathrm{~km}$ reach of the channel from the mouth to the Zbytinský Brook was reverted using concrete components into the uniform shape of a trapezoid cross-section profile with an incline of $1: 1.5$. In spring 2005, the abovementioned partial restoration of the brook and adjacent reach of the Zbytinský Brook under the village of Zbytiny was carried out. The concrete fortification was removed, the channel bank incline was changed and the channel bed was equipped with stone rapids. Small bends were created on the short reach under the road bridge. The restored channel was left to develop spontaneously. The restoration was carried out in a different place than the original course before 1970 .

\section{Geodetic measurement of the restored channel}

At present, the results from the seven repeated measurements of the cross-section profiles (23 June 2005, 13 October 2005, 19 April 2006, 25 October 2006, 11 April 2007, 24 October 2007, 10 April 2008) and from the six longitudinal profiles (without spring 2005) are available. Since the restoration was carried out, the restored channel has displayed relatively large dynamics, manifested by intensive stream bed erosion and bank erosion on one side and by extensive fluvial depositing on the channel bed on the other side. In the first six months, the channel in almost all monitored profiles (1-10) experienced small to medium deepening ranging from 5 to $20 \mathrm{~cm}$. From autumn 2005 to spring 2006, the profiles remained the same depth level with some exceptions. The profiles widened at the bottom by approximately $20 \mathrm{~cm}$. Bank erosion and the accumulation of the transported material led to a spontaneous development of small bends where the largest changes in terms of depth and width occur. Between spring 2006 and autumn 2006, dramatic changes occurred in the monitored reach connected with the above-mentioned significant rainfall-runoff events. Particularly on 12 July 2006, the water level reached $66 \mathrm{~cm}$ below the road bridge. The channel changed considerably, significant stream bed and bank erosion occurred (the monitored cross profiles experienced deepening of more than $30 \mathrm{~cm}$; bank erosion in some cut banks was up to 1 metre). On the contrary, some previously deepened profiles were covered by a thick sediment layer of up to $25-30 \mathrm{~cm}$, thereby reaching the original level of spring 2005. Changes are also apparent in the longitudinal profile 

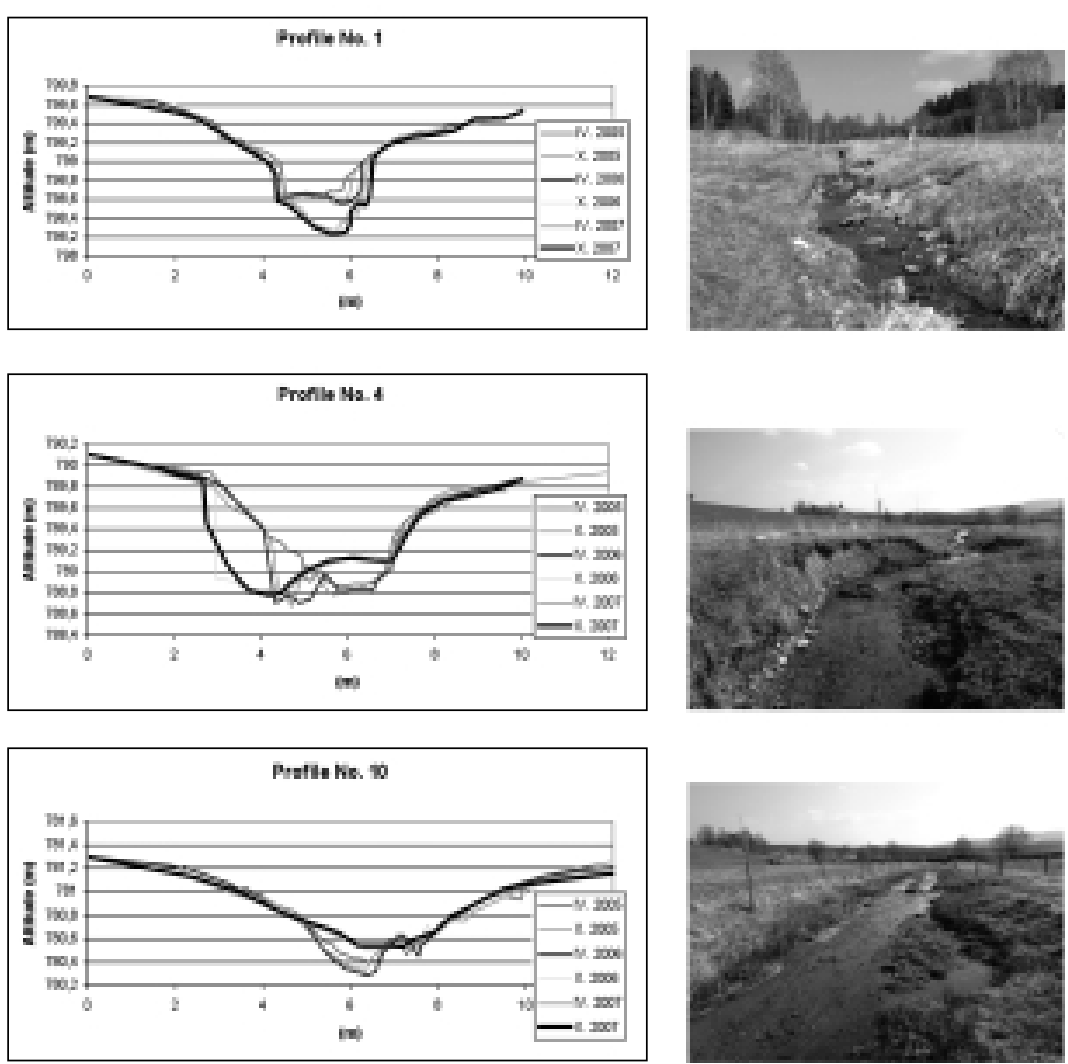

Figure 6: Examples of the cross-section profiles, 2005-2007. Photo: Kliment

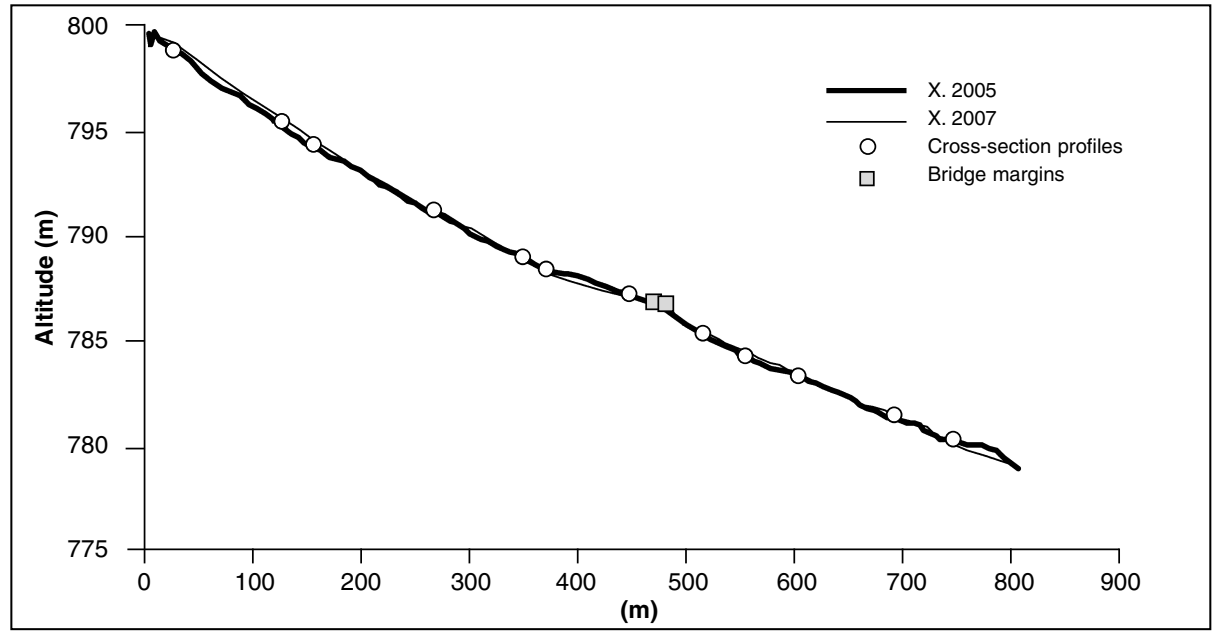

Figure 7: Changes in the longitudinal profile of the restored channel, 2005-2007 
of the brook. The changes in the stream bed surface level are up to $40 \mathrm{~cm}$ (Fig. 6). While some bends were deepened, the accumulation parts of the profile were filled up, which resulted in the disappearance of other smaller bends. This, in fact, made the channel straight again. Regarding the dynamics of the longitudinal profile of the brook, the road bridge is beginning to be an obstacle to the flow. The last measurements in 2007 and in spring 2008 did not display any significant naturally caused changes in the channel, partly since there were neither significant rainfallrunoff events nor any larger discharge due to the melting of snow cover during this time. The channel is in the same condition as in spring 2006 with some exceptions such as the extension of eroded reaches, the receding of the channel edge (especially in the case of the cut banks), and certain stream bed accumulation and bank erosion at the start and end of the transport reaches (Fig. 7).
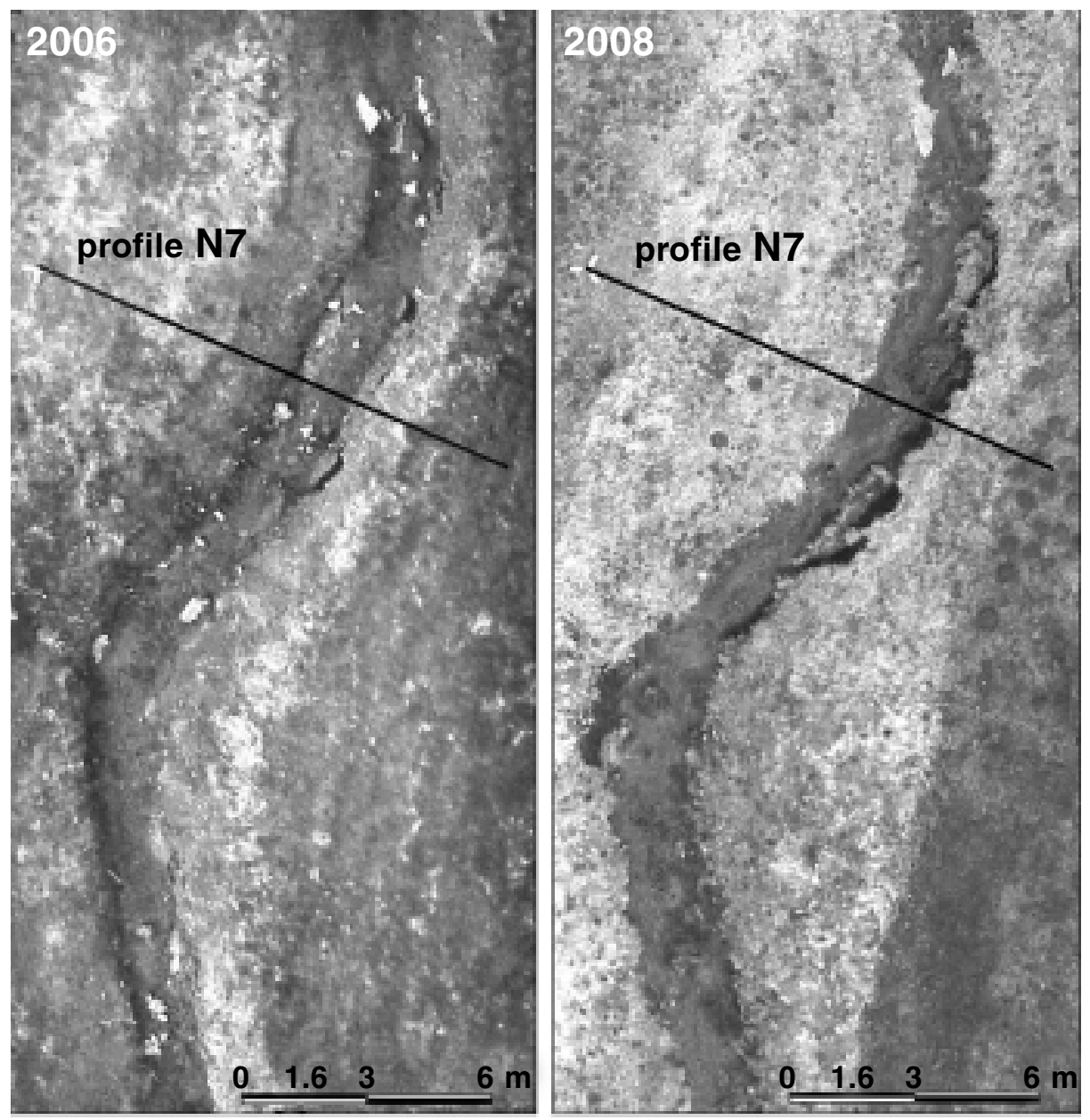

Figure 8: Examples of geo-referenced images taken by flying models in 2006 and 2008 (surrounding of the profile N7) 
Taking images from low-flying radio-operated models was used as an experimental and alternative method to geodetic measurements of the stream bed. The purpose was to obtain images for the systematic monitoring of the stream-bank development and areas of accumulations and erosions in the whole length of the Sviňovický Brook and its neighbourhood, both in horizontal and vertical directions. The images were taken on 3 May 2006, 12 April 2007 and 24 April 2008, i.e. at the beginning of the vegetation period. A radio-operated model of a plane was used for the first flight in 2006. The images were taken from an approximate flying height of $70 \mathrm{~m}$. Because of problems with keeping the model just above the stream axis, the producer and owner of the flying

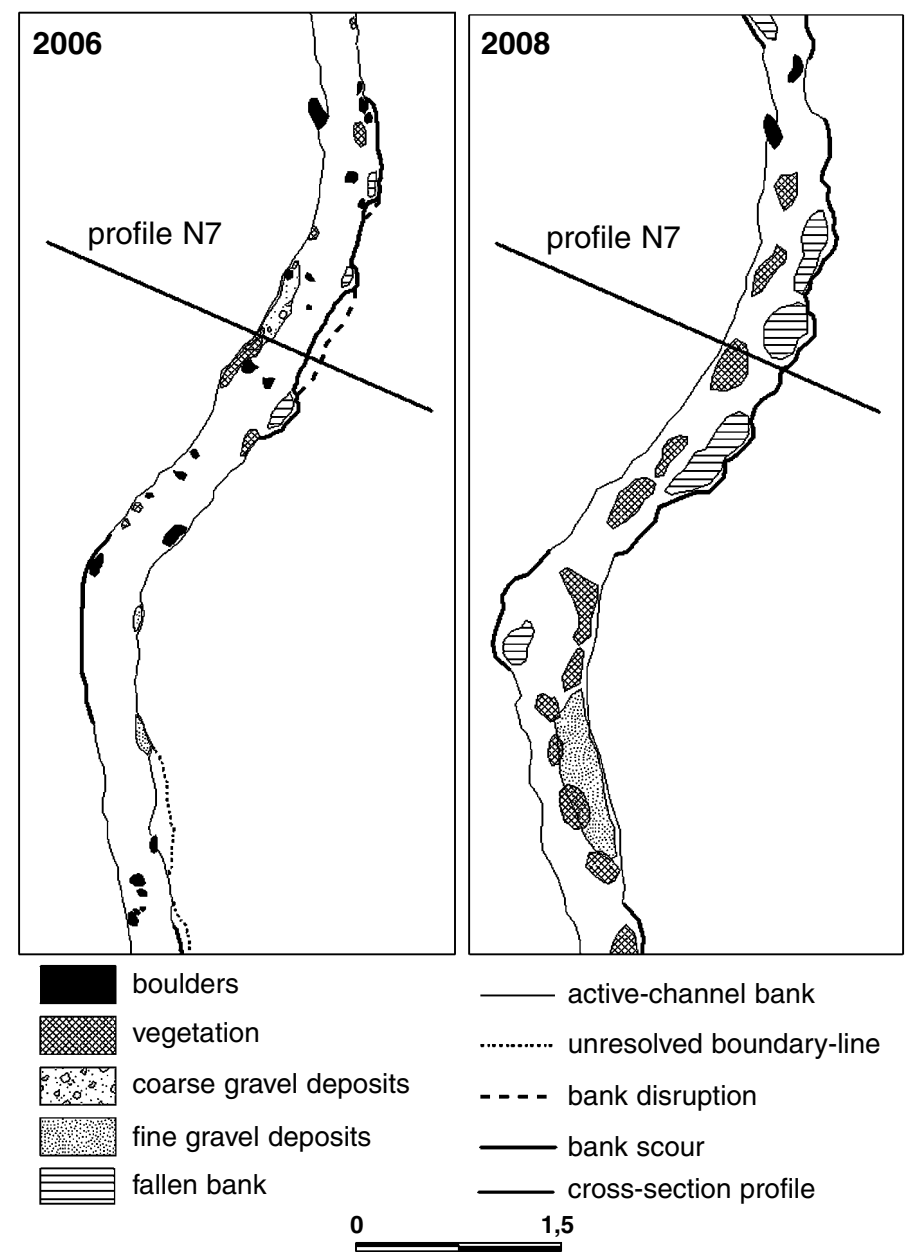

Figure 9: Examples of the interpretation of the images taken by flying models in 2006 and 2008 (surrounding of the profile N7) 
devices suggested using a model of a helicopter in spring 2007. This model enabled images to be taken from a lower flying height, allowing increased resolutions. The photogrammetric processing of these images (about 600 files) proved to be time consuming. Moreover, the geo-referencing of some images was impossible due to the low number of control points. Thus, taking images from the model plane proved to be more suitable for the purpose of this investigation and was used again in spring 2008.

So far, the images taken in 2006 and 2008 have been evaluated. The images were geo-referenced using the method of projective transformation for the present. Thanks to the high resolution, the images taken by the low-flying model enabled us to make a relatively detailed interpretation of the selected fluvial-geomorphological shapes and, at the same time, to observe how the channel is gradually becoming overgrown by vegetation. Special attention was paid to the identification of the course and changes in the active-channel bank and in the marked bank boundaries, particularly bank scours, bank disruptions and fallen banks. Location and changes in fine and coarse gravel deposits and large boulder deposits on the stream bed were also identified, as was the coverage of the stream bed by vegetation.

Fig. 8 and Fig. 9 can serve as examples of the processing and interpretation of the aerial images taken by the flying models in 2006 and 2008. These are images of the restored reach of the channel under the road bridge where, the caving banks were not filled with quarried stones at the end of 2007. The widening of the channel which occurred after the significant rainfall-runoff event in summer 2006, with bank erosion and subsequently falling of wash bank into the channel, is clearly visible in the pictures. Smaller boulders were taken further down the stream. The vegetation growth plays a considerable role in stabilizing the stream bed accumulation.

\section{Ecohydrological monitoring}

The basis for the evaluation of the river quality is the ecological status, which is defined based on the hydromorphological, hydrochemical and hydrobiological parameters (EC WFD 2000). The hydrochemical monitoring of the area studied is based on taking samples of water quarterly. The water samples were analysed in the Environmental Laboratory, Faculty of Science, Charles University in Prague using standardized methods. The following indicators were determined: conductivity, $\mathrm{pH}$, $\mathrm{KNK}_{4,5}, \mathrm{ZNK}_{8,3}$, hardness, $\mathrm{Ca}^{2+}, \mathrm{Mg}^{2+}, \mathrm{COD}, \mathrm{N}-\mathrm{NH}_{4}^{+}, \mathrm{N}-\mathrm{NO}_{2}^{-}, \mathrm{N}-\mathrm{NO}_{3}^{-}, \mathrm{P}-\mathrm{PO}_{4}{ }^{3-}, \mathrm{Cl}^{-}$, $\mathrm{Fe}, \mathrm{Mn}$, humic substances (from 2008) and also temperature and dissolved $\mathrm{O}_{2}$, which are measured directly in the field. The research of the water quality is carried out in the profile of the Sviňovický Brook and in four other locations which document the quality in its close vicinity - see Fig. 10. These profiles are Zbytinský Brook above and below the village of Zbytiny, the left side tributary of Zbytinský Brook in the village of Zbytiny and the Tetřívčí Brook. The profiles mentioned are important as they can be used for cross-comparative analyses. Classification into the water quality classes according to ČN 757221 is only approximate because of the small number of samples taken.

The largest point pollution source in the Zbytinský Brook catchment is the village Zbytiny itself. At present, a sewage plant is being built here for 510 people equivalent quotient (EQ) and sewerage. This source affects the profile Zbytinský Brook below. 


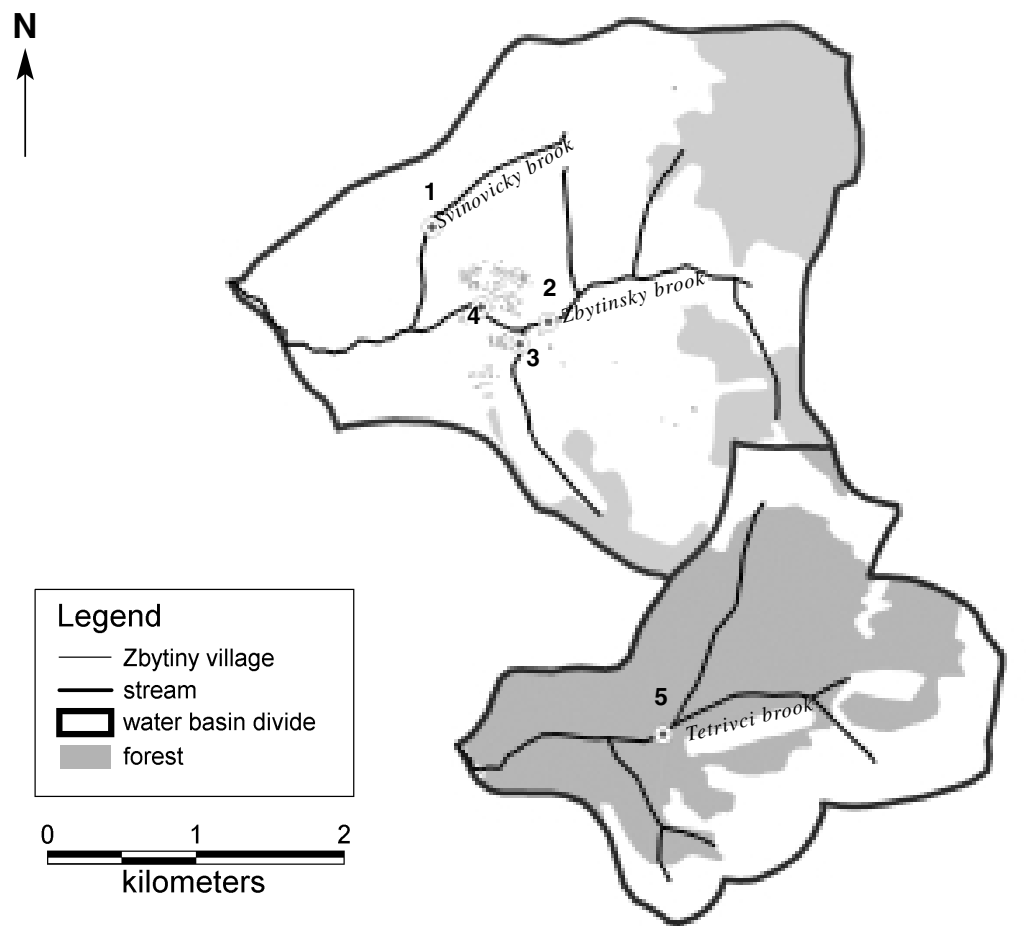

Figure 10: Location of water quality profiles

A point pollution source also affects the water basin of the Tetřivčí Brook, more specifically the sewage plant for 78 EQ located in the premises of the agricultural cooperative ZD Ktiš in the village of Křšstanov. The other monitored profiles are not affected directly by a point pollution source (Hryzáková 2008). Agricultural activities must be mentioned as other sources of pollution, particularly the intensive cattle farming and other non-point pollution and diffuse pollution sources connected with anthropogenic activities in the river basin. The increased values of COD (chemical oxygen demand) in all the profiles monitored are probably connected with the higher concentration of humic substances. The values of $\mathrm{pH}$ are in the range of 6-7.6; iron concentration is $0-0.41 \mathrm{mg} . \mathrm{l}^{-1}$. The hydrochemical analyses carried out display a low level of pollution in the restored reach of the Sviňovický Brook in most of the parameters monitored. The prevailing class of the water quality are 1 and 2 class with the exception of COD. In the case of the COD parameter, the quality of water reaches $3^{\text {rd }}$ class, which means polluted water.

Regarding the parameters of conductivity and $\mathrm{N}-\mathrm{NO}_{3}^{-}$, the restored reach of the Sviňovický Brook (the Sviňovický Brook profile) displays the highest burden. An increased concentration of chlorides was identified in this profile. The source of the pollution is probably the intensive cattle farming on the pastures in the immediate vicinity of the channel of the brook. The recorded concentration of $\mathrm{N}_{-} \mathrm{NO}_{3}{ }^{-}$falls into the $2^{\text {nd }}$ quality class, i.e. only mild pollution - see Fig. 11 . The results of the hydrochemical 


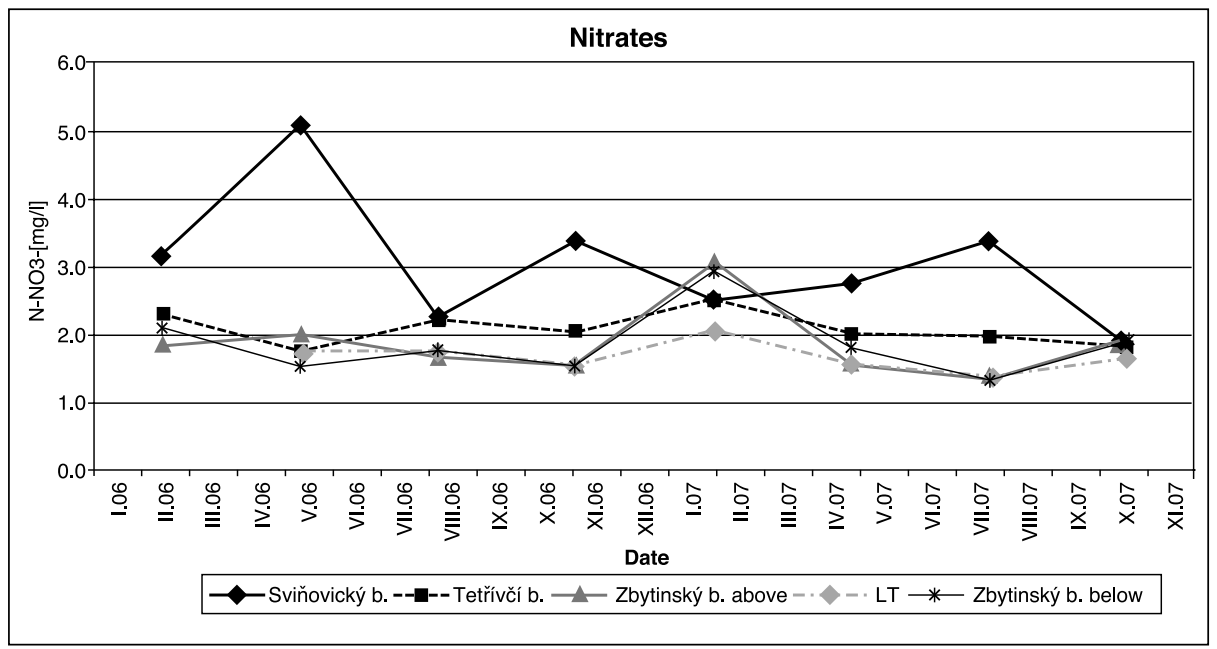

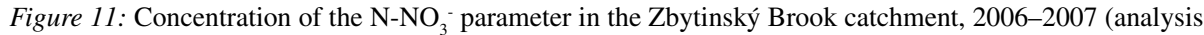
by the Environmental Laboratory, Faculty of Science, Charles University in Prague, K. Hryzáková)

analysis confirmed the existence of a significant point pollution source in the water basin of the Zbytinský Brook: the village of Zbytiny. Specifically, concentrations of $\mathrm{COD}$, conductivity, $\mathrm{N}-\mathrm{NH}_{4}{ }^{+}$and $\mathrm{P}-\mathrm{PO}_{4}{ }^{3-}$ are higher. The situation will undoubtedly improve after the sewage treatment plant Zbytiny comes into operation.

The ecohydromorphological status was mapped on the restored channel of the total length of $720 \mathrm{~m}$; the fortified channel of the upper part of the Sviňovický Brook measuring $280 \mathrm{~m}$ was also mapped. Homogeneous sections of $40 \mathrm{~m}$ were defined. The characteristics of the channel of the brook, riparian belt and flood plain were mapped during the field research. The overview of the parameters assessed can be found in table 1. This is a slightly modified version of the EcoRivHab method (Matoušková 2003, 2007).

The overall ecomorphological condition of the brook after the restoration can be classified as being in the $2^{\text {nd }}$ ecomorphological grade (EG), which means that it is almost natural, affected only mildly by anthropogenic activity. The $1^{\text {st }}$ EG has not been achieved mainly because some parameters have not scored good points evaluations, e.g. altered discharge characters (note: the influence of the drainage and the alterations left on the upper part of the brook), banks in some reaches reverted by scattering quarried stone, lower diversity of microhabitats and absence of group vegetation of potentially natural variety in the riparian belt. The restorations carried out have concentrated on unfortifying the channel and planting bank vegetation which was previously planted mainly in line along the banks. However, due to the instability of the banks, some trees have died. The restoration did not include planting the riparian belt in the wider surrounding of the brook. The $4^{\text {th }} \mathrm{EG}$ was recorded in only one assessed section (in SVI011). This is a section where the brook flows through the bridge culvert under the road Prachatice-Zbytiny. The alteration carried out affects the low diversity of hydromorphological mesostructures and microstructures in the given section and in the adjacent sections - see Fig. 12. 
Table 1: Parameters assessed in the ecohydromorphological mapping using EcoRivHab method

\begin{tabular}{|c|c|c|c|}
\hline $\begin{array}{l}\text { Ecomorphological } \\
\text { zones }\end{array}$ & $\begin{array}{l}\text { Group of } \\
\text { parameters }\end{array}$ & Parameters & $\begin{array}{l}\text { Assessment } \\
\text { type }\end{array}$ \\
\hline \multirow[t]{21}{*}{ Channel } & $\begin{array}{l}\text { Morphology and } \\
\text { channel geometry }\end{array}$ & River valley, gradient & $\mathrm{V}$ \\
\hline & & Curvature & $\mathrm{S}(1,3,5)$ \\
\hline & & Channel character and shape & $\mathrm{S}(1,2,3,4,5)$ \\
\hline & & Deepening of the channel & $\mathrm{S}(1,2,3,4,5)$ \\
\hline & & Connectivity to ground water & $\mathrm{S}(1,3,5)$ \\
\hline & Longitudinal profile & Steps & $\mathrm{S}(1,2,3,4,5)$ \\
\hline & & Erosion and accumulation forms & $\mathrm{F}(1,3,5)$ \\
\hline & & Flow patterns & $\mathrm{F}(1,3,5)$ \\
\hline & & $\begin{array}{l}\text { Variation of depth (number of riffles } \\
\text { and pools) }\end{array}$ & $\mathrm{S}(1,2,3,4,5)$ \\
\hline & & Modification of outflow & $\mathrm{S}(1,3,5)$ \\
\hline & Cross profile & Variation of width & $\mathrm{F}(1,3,5)$ \\
\hline & Bottom structures & Substrate type & $\mathrm{V}$ \\
\hline & & Bottom modification & $\mathrm{S}(1,2,3,4,5)$ \\
\hline & & Diversity of microhabitats & $\mathrm{F}(1,3,5)$ \\
\hline & Bank structures & Character of bank vegetation & $\mathrm{S}(1,2,3,4,5)$ \\
\hline & & Structure of bank vegetation & $\mathrm{S}(1,2,3,4,5)$ \\
\hline & & Bank modification & $\mathrm{S}(1,2,3,4,5)$ \\
\hline & & Stability of banks & $\mathrm{S}(1,2,3,4,5)$ \\
\hline & Surface water quality & Hydrochemical features & $\mathrm{S}(1,2,3,4,5)$ \\
\hline & & Hydrobiological features & $\mathrm{S}(1,2,3,4,5)$ \\
\hline & & Occurrence of drainage outlets & V \\
\hline \multirow[t]{3}{*}{ Riparian belt } & & Existence & $\mathrm{F}(1,3,5)$ \\
\hline & & Character and structure of vegetation & $\mathrm{S}(1,2,3,4,5)$ \\
\hline & & Land use & $\mathrm{S}(1,2,3,4,5)$ \\
\hline \multirow[t]{3}{*}{ Flood plain } & & Prevailing land use & $S(1,2,3,4,5)$ \\
\hline & & Occurrence of flood protection measures & $\mathrm{S}(1,3,5)$ \\
\hline & & Retention capacity & $\mathrm{F}(1,3,5)$ \\
\hline
\end{tabular}

Abbreviations used: F - frequency assessment, S - score-based assessment, V - verbal assessment

The character of the habitat of the originally altered brook can be classified as $3^{\text {rd }}$ EG, which means a medium level of anthropogenic influence. The channel zone of the brook received the worst evaluation due to the concrete fortification of the banks and stream bed, low diversity of channel depth and width, and low diversity of microhabitats. It scored mainly $3^{\text {rd }}$ and $4^{\text {th }}$ EG. The fortification carried out is broken in some reaches and the banks are fairly unstable. The existing riparian belt has, above all, a positive influence on the evaluation of the character of the whole habitat of the brook. 


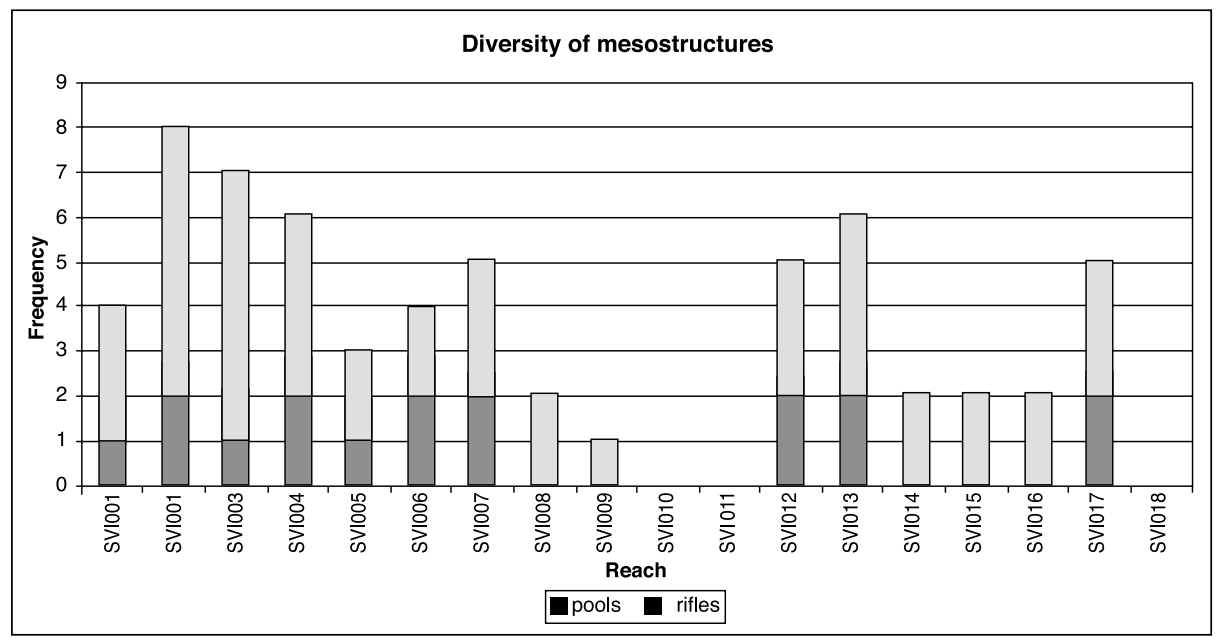

Figure 12: Diversity of hydromorphological mesostructures in the restored reach - number of riffles and pools in individual sections

As part of the ecohydrological research, the flow speeds were also monitored using the floating method in the restored sections SVI001, SVI005, SVI010 and in the modified section SVI032. The fastest speeds were recorded in the fortified section. They were between $1 / 4$ and $1 / 2$ higher.

\section{Discussion and conclusion}

The study submitted summarizes the knowledge gained so far from research lasting over two years into the fluvial-morphological and ecohydrological monitoring of the restored Sviňovický Brook channel. It is based particularly on repeated geodetic measurements of the cross-section and longitudinal profiles which were carried out regularly in six-month intervals with regard to past significant rainfall-runoff events. The aerial images taken by low-flying model plane and a helicopter, which are currently being processed photogrammetrically and interpreted, will also contribute greatly to the results of the research. Besides initiated methods the ecohydrological monitoring have been applied.

Since the restoration was carried out, the restored channel has displayed relatively large dynamics consisting of channel deepening which reached gentle to medium levels, subsequent slope erosion, and widening of the channel in the bends. The development of the restored channel was considerably affected by a large rainfallrunoff event on 12 July 2006 when the above-mentioned dramatic changes occurred in the reach monitored. The intensive eroding-depositing processes remodelled the channel; the longitudinal profile of the brook was levelled. In the following period, the channel continued to widen gently, particularly in the bends and as a result of the falling of eroded banks breaking off in the section under the road bridge. 
Although the condition of the channel is relatively stabilized and the banks and stream bed are in various stages of fortification thanks to the vegetation, the owner of the brook, the water authority AWMA Prachatice, decided to intervene in the natural development of the channel. At the end of 2007, quarried stone was brought to the largest bank caves in the section of the brook above the road bridge. The lower section of the brook has, so far, been left to develop naturally.

The analysis of historical maps and photographs has identified relatively great, irreversible changes in the course of the monitored channel associated with amelioration improvement in the 1970s and 1980s. As a result of the straightening of the brook, its mouth into the Zbytinský Brook shifted downstream which, together with the alterations carried out, may have contributed to the increase in discharge from the area. The subsequent research will gather new facts concerning the effect of mentioned bank erosion protective measures.

Due to the substantial instability of the banks of the reverted channel in the upper part of the brook and in order to reduce the flow speed in the central and lower parts of the restored brook, we recommend that subsequent restoration of the upper part of the Sviňovický Brook should be carried out. Above all, the current fortification of the banks and stream bed should be removed, the cross-section profile of the channel should be made shallower and the course of the channel should be renewed. The channel of the Sviňovický Brook in the source area could serve as an example as some natural sections were found there.

The ecohydrological monitoring confirmed a low level of pollution of the restored reach of the Sviňovický Brook. The highest concentrations were recorded for the following parameters: $\mathrm{COD}$, conductivity and $\mathrm{N}-\mathrm{NO}_{3}{ }^{-}$. These substances originate from non-point and diffuse pollution sources. Their reduction could be achieved by more comprehensive restoration, both in longitudinal and cross-section profile, including creating functional riparian belts with an optimum variety of bushes and woody plants, solving the drainage mouth, and eliminating cattle farming in the close vicinity of the brook.

Regarding the study of the natural hydromorphological development of the restored channel, it is a pity that the banks were reverted in some sections above the road by quarried stones. The natural process of channel formation was again affected by an anthropogenic factor. For future evolution, it will be interesting to assess the kind of impact the alterations carried out will have on the channel-forming processes. We think that the methods and analytical approaches applied so far have proven to be correct and brought valuable results in terms of the documentation of the condition and developments of the restored channel of the Sviňovický Brook. All applied field and photogrammetric methods will be used in further research. In the case of the photogrammetric method, taking images using a low-flying model of a helicopter was not very successful, so a model plane we recommend for further usage. The monitoring of the rainfall-runoff regime will continue. Assessment criteria based on the ecohydromorphological mapping and water quality monitoring carried out will be used to determine the restoration effect. For the assessment of restoration effect we recommend at least to use geodetic measurements of the cross-section and longitudinal profiles, monitoring of the rainfall-runoff regime, water quality monitoring based on 
hydrochemical parameters and macroinvertebrates, ecohydromorphological survey of channel and riparian zone.

\section{Acknowledgements}

This work was supported by the project MSM 0021620831 Geographical systems and risk processes in the context of global changes and European integration and by the project VaV SM/2/57/05 "Long-term changes in fluvial ecosystems in floodplains affected by extreme floods".

\section{References}

BROOKES, A. (1988): Channelized rivers, Perspectives for environmental management. John Wiley \& Sons, Chichester.

GREŠKOVÁ, A., LEHOTSKÝ, M., PASTUCHOVÁ, Z. (2007): Morfohydraulická štruktúra dna koryta malého vodného toku a spoločenstvá makrozoobentosu. Geografický časopis. 59 (1), 25-45.

HUBAČÍKOVÁ, V., OPPELTOVÁ, P. (2008): Hodnocení provedených revitalizací na vybraných tocích jižní Moravy. In: Ekosystémové služby říční nivy (eds. Pikhart, Benedová, Křováková). USBE AV ČR, Třeboň, 86-87.

HUJSLOVÁ, J. (2007): Dynamika revitalizovaného koryta Sviňovického potoka. Bakalářská práce, PřF UK v Praze, Praha.

HUJSLOVÁ, J., KLIMENT, Z., MATOUŠKOVÁ, M., POTƯČKOVÁ, M., ŠOBR, M. (2007): Sledování dynamiky revitalizovaného koryta Sviňovického potoka. In: Změny v krajině a povodňové riziko (Langhammer ed.), UK Praha, 227-231.

HRYZÁKOVÁ, K. (2008): Srovávací studie hydrochemismu povrchových vod v povodí Rolavy, horní Blanice a Liběchovky. In: Ekohydrologický monitoring vodních toků v kontextu evropské Rámcové směrnice ochrany vod (Matoušková ed.). UK Praha, GA ČR (v tisku).

JUST, T., MATOUŠEK, V., DUŠEK, M, FISCHER, D., KARLÍK, P. (2005): Vodohospodářské revitalizace a jejich uplatnění v ochraně před povodněmi. Český svaz ochránců př́rody. Praha.

KERN, K. (1994): Grundlagen naturnaher Gewässergestaltung. Geomorfphologische Entwicklung von Fließgewässern. Springer-Verlag, Berlin, Heidelberg.

KOHOUTEK, P., TUČEK, J. (2002): Projekt stavby Revitalizace toku Zbytiny. Projekta Tábor - nepublikováno.

KRAUS, K. (2001): Photogrammetry, Vol. 1, Dümler, Bonn.

MATOUŠKOVÁ, M. (2003): Ekohydrologický monitoring vodních toků jako podklad pro revitalizaci vodních ekosystémů. Disertační práce Katedra fyzické geografie a geoekologie, PřF UK v Praze, Praha.

MATOUŠKOVÁ, M. (2007): Ekohydrologický monitoring vodních toků v kontextu Rámcové směrnice ochrany vod EU. Závěrečná výzkumná zpráva projektu GA ČR č. 205/02/P102, PřF UK v Praze a GA ČR, Praha.

POTƯČKOVÁ, M., KLIMENT, Z. (2007): Application of Non-Metric Images for Monitoring of the Svinovicky Brook Channel. International Conference "Evolution of geographic global system and risk processes in global context", 21-22. 9. 2007, Praha, poster.

ŠINDLAR, M. (1998): Dynamika a ochrana přirozených ekosystémů vodních toků. Závěrečná výzkumná zpráva VaV projekt. MŽP ČR, Praha.

ZUNA, J. (2001): Efekt revitalizačních úprav potočních koryt. Vodní hospodářství, 51 (8).

VRÁNA (2004): Revitalizace malých vodních toků - součást péče o krajinu. Consult Praha, Praha.

WAAL, L., LARGE, A., WADE, M. (2000): Rehabilitation of rivers. Principles and Implementation. Wiley, Chichester. 


\section{Fluviální dynamika a vybrané metody ekohydrologického monitorování koryta revitalizovaného Sviňovického potoka}

Příspěvek je zaměřen na monitoring a hodnocení zrevitalizovaného Sviňovického potoka u obce Zbytiny v povodí horní Blanice. Hlavní pozornost byla věnována dynamice fluviálně-morfologického vývoje nového koryta. Je založena na opakovaných geodetických zaměřováních příčných a podélných profilů v pravidelných půlročních intervalech ve vztahu k proběhlým významným srážko-odtokovým epizodám. Vedle geodetických metod byly v území aplikovány fotogrammetrické metody s využitím nasnímkování území z nízkoletících modelů. Rozvolněné koryto vykazovalo od provedené revitalizace poměrně velkou dynamiku spočívající v mírném až středním zahlubování koryta, provázeném podemíláním svahů a rozšiřováním koryta v místě zákrutů. K prozatím největší modelaci revitalizovaného koryta došlo při povodni v červenci 2006, která vyvolala na malém toku hloubkové změny v rozmezí více než $30 \mathrm{~cm}$ a šířkové změny až $1 \mathrm{~m}$ a vytvořila nové podmínky pro další vývoj koryta. I přes relativně stabilizovaný stav koryta a různý stupeň zpevnění břehů a dna vegetací se rozhodl vlastník toku, správa ZVHS Prachatice, zasáhnout do přirozeného vývoje zrevitalizovaného koryta. Ke konci kalendářního roku 2007 byl proveden závoz lomového kamene k největším nátržím v úseku toku nad silničním mostem. Dolní úsek toku byl prozatím ponechán přirozenému vývoji.

Samostatná pozornost byla věnována změnám trasy sledovaného koryta $\mathrm{v}$ historické době $\mathrm{v}$ období 1843-2005 na základě analýzy mapových podkladů a leteckých snímků. Analýzou byly zjištěny poměrně razantní, v dnešní době již nenávratné změny trasy sledovaného koryta spojené s melioračními úpravami v 70.-80. letech minulého století.

V návaznosti na fluviálně-morfologický průzkum byl prováděn průzkum kvality vody na základě základních hydrochemických ukazatelů a dále hodnocení ekohydromorfologických struktur kvality habitatu vodního toku. Provedený monitoring potvrdil nízkou míru znečištění revitalizovaného úseku Sviňovického potoka. Nejvyšší koncentrace byly zaznamenány u parametrů $\mathrm{CHKS}_{\mathrm{Mn}}$ (III. tř́ída jakosti), konduktivita a dusičnanový dusík (II. třída jakosti). Zdrojem těchto látek jsou rozptýlené a plošné zdroje znečištění. Jejich snížení by napomohlo komplexnější pojetí revitalizace jak v podélném, tak př́ičném profilu včetně vytvoření funkčních doprovodných vegetačních pásů s optimální skladbou dřevin a keřů, vyřešení vyústění drenážních výpustí a eliminace chovu skotu v bezprostřední blízkosti toku. Dostatečně široké a funkční doprovodné vegetační pásy by znamenaly rovněž zlepšení celkového ekohydromorfologického stavu koryta vodního toku. Mapování ekohydromorfologického stavu bylo provedeno na revitalizovaném úseku v celkové délce 720 m a dále bylo provedeno mapování upraveného úseku na horním toku Sviňovického potoka $\mathrm{v}$ délce $280 \mathrm{~m}$. Při terénním průzkumu byly mapovány charakteristiky koryta toku, doprovodných vegetačních pásů a údolní nivy. Z pohledu studia přirozeného hydromorfologického vývoje revitalizovaného koryta je škoda, že došlo v několika úsecích nad silnicí k opevnění břehů kamenným pohozem. Do přirozeného procesu formování koryta tedy opět zasáhl antropogenní faktor.

Milada Matoušková Charles University in Prague Faculty of Science

Department of Physical Geography and Geoecology

Albertov 6

12843 Prague 2

Czech Republik

e-mail: matouskova@natur.cuni.cz.

phone: +420221951412

fax: +420221951367 